\title{
Kepatuhan Mengonsumsi Tablet Fe Selama Hamil Berhubungan dengan Kejadian Bayi Berat Lahir Rendah (BBLR) di Kabupaten Bantul
}

\author{
Fatimatasari ${ }^{1}$, Hamam Hadi ${ }^{2}$, Nur Indah Rahmawati ${ }^{3}$ \\ 1, 2, 3Sekolah Tinggi Ilmu Kesehatan Alma Ata Yogyakarta \\ Jalan Ringroad Barat Daya No 1 Tamantirto, Kasihan, Bantul Yogyakarta
}

\begin{abstract}
Abstrak
Penurunan angka kematian bayi di Indonesia belum belum mencapai target 8 tujuan emas MDG'S. Pada tahun 2010 penyebab kasus kematian neonatal terbanyak disebabkan karena bayi berat lahir rendah (BBLR) dan kasus terbanyak terjadi di Kabupaten Bantul. Ibu hamil dengan anemia merupakan faktor resiko kejadian BBLR, sedangkan kasus anemia yang paling sering dijumpai pada ibu hamil adalah akibatkekurangan zat besi. Pemberian tablet Fe minimal 90 tablet dapat mengatasi anemia kekuarangan zat besi pada ibu hamil. Penelitian case control ini bertujuan untuk mengetahui hubungan antara tingkat kepatuhan Ibu hamil mengkonsumsi tablet Fe dengan kejadian bayi berat lahir rendah (BBLR). Sampel penelitian adalah 132 ibu melahirkan di RSUD Panembahan Senopati Bantul terdiri dari 66 Ibu yang melahirkan bayi BBLR sebagai kelompok kasus dan 66 Ibu yang melahirkan bayi tidak BBLR sebagai kelompok kontrol. Hasil pengumpulan data didapatkan 53\% sampel masih mengkonsumsi tablet Fe kurang dari 90 tablet. Hasil analisa data dengan uji statistik didapatkan hasil OR=2,09 (95\% Cl [1,040 - 4,194]) dan $x_{2}=4,38$ dengan $p$ value $=0,036$. Kesimpulan dari penelitian ini adalah ada hubungan antara tingkat kepatuhan ibu hamil mengkonsumsi tablet Fe dengan kejadian Bayi berat lahir rendah (BBLR) dengan resiko ibu hamil yang mengkonsumsi tablet Fe kurang dari 90 tablet mempunyai resiko 2,1 kali lebih besar untuk melahirkan bayi BBLR dibandingkan dengan ibu yang mengkonsumsi tablet Fe 90 tablet atau lebih.
\end{abstract}

Kata Kunci: tingkat kepatuhan minum tablet Fe selama hamil, BBLR

Info artikel:

Artikel dikirim pada 29 agustus 2013

Artikel diterima pada 29 agustus 2013

\section{PENDAHULUAN}

Angka Kematian Bayi (AKB) adalah jumlah bayi yang meninggal sebelum mencapai usia satu tahun yang dinyatakan dalam 1.000 kelahiran hidup pada tahun yang sama(1). Salah satu penyebab kematian bayi di Indonesia adalah BBLR.BBLR (Bayi Berat Lahir Rendah) adalah Bayi lahir dengan berat badan kurang dari berat badan seharusnya untuk masa kehamilan, hal ini karena mengalami gangguan pertumbuhan dalam kandungan(2).

Bayi Berat Lahir Rendah (BBLR) merupakan penyebab kematian neonatal terbanyak di Provinsi DIY. Berdasarkan hasil Riset Kesehatan Dasar (Riskesdas) tahun 2010, dari 241 kasus kematian neonatal di DIY, 98 diantaranya disebabkan karena BBLR dengan kasus terbanyak terjadi di Kabupaten Bantul yaitu sebanyak 31 kasus(3).

Keadaan obstetrik ibu, keadaan janin, nutrisi, kadaan sosial ekonomi, dan kebiasaan merupakan faktor predisposisi terjadinya kejadian Bayi Berat Lahir Rendah (BBLR).Dari faktor nutrisi, anemia dalam kehamilan yang disebabkan karena rendahnya asupan zat besi merupakan masalah yang sangat sering terjadi. Anemia ibu hamil memberi pengaruh pada kehamilan dan janinnya baik dalam kehamilan, persalinan maupun nifas.Anemia dalam kehamilan yang sering dijumpai adalah anemia akibat kekurangan zat besi. Kekurangan ini dapat disebabkan karena kurang masuknya unsur zat besi dalam makanan(4).

Angka anemia ibu hamil di Provinsi DIY sebesar $20,95 \%$. Prevalensi ibu hamil anemia di Provinsi DIY ini masih berada di atas ambang batas masalah gizi yaitu 20\%(5). Pemberian tablet $\mathrm{Fe}$ sehari 1 tablet (60 mg besi elemental dan $0,25 \mathrm{mg}$ asam folat) yang diberikan minimal 90 hari masa kehamilan dapat mencegah terjadinya anemia pada ibu hamil(6). Berdasarkan Riset Kesehatan Dasar (Riskesdas) tahun 2010 secara nasional 19,3\% ibu hamil melaporkan tidak pernah meminum tablet $\mathrm{Fe}$, 
dan hanya $18,0 \%$ ibu hamil yang melaporkan minum tablet Fe 90 tablet atau lebih(5). Studi pendahuluan yang dilakukah oleh peneliti di RSUD Panembahan Senopati Bantul Yogyakarta menunjukkan bahwa selama tahun 2011 terdapat 248 bayi dengan berat badan lahir rendah (BBLR) dari 3111 kelahiran hidup. Artinya, rata-rata perbulan terdapat 20 bayi yang lahir dengan berat badan lahir rendah.

Dengan melihat tingginya kejadian bayi berat lahir rendah dan rendahnya konsumsi tablet Fe ibu hamil di kabupaten Bantul, peneliti ingin mengetahui apakah ada hubungan antara kepatuhan ibu hamil mengkonsumsi tablet Fe dengan kejadian bayi berat lahir rendah di Kabupaten Bantul.

\section{BAHAN DAN METODE}

Penelitian ini menggunakan metode case control.Sampel penelitian sebanyak 132 ibu yang pernah melahirkan di RSUD Panembahan Senopati Bantul. Yaitu yang melahirkan antara bulan Oktober 2011 hingga Februari 2012 dan berdomisili di Kabupaten Bantul. Sampel dibagi menjadi kelompok kasus dan kelompok kontrol. Kelompok kasus adalah ibu yang melahirkan bayi dengan berat badan lahir kurang dari 2500 gram (BBLR) dan kelompok kontrol adalah ibu yang melahirkan bayi dengan berat badan 2500 gram atau lebih (tidak BBLR). Tingkat kepatuhan konsumsi tablet Fe selama hamil dinilai berdasarkan keseluruhan jumlah tablet $\mathrm{Fe}$ yang diminum selama hamil. Dikatakan patuh jika selama hamil ibu mengkonsumsi tablet Fe 90 tablet Fe atau lebih dan dikatakan tidak patuh mengkonsumsi tablet Fe kurang dari 90 tablet.

Penelitian dilakukan bulan Mei sampai dengan Juli 2012. Penelitian dilakukan dengan mencari data ibu yang melahirkan bayi di RSUD Panembahan Senopati Bantul yang akan dijadikan sampel dengan melihat rekam medis pasien, melakukan wawancara langsung dengan responden, dan melakukan klarifikasi ulang jawaban responden dengan catatan pemberian tablet Fe dalam buku KIA.

\section{HASIL DAN PEMBAHASAN}

Kasus BBLR tersebarhampir di seluruh Kecamatan di Kabupaten Bantul. Kasus terbanyak tedapat di Kecamatan Bantul dengan jumlah 12 kasus atau sebesar $18,2 \%$. Tingkat kepatuhan ibu mengkonsumsi tablet Fe selama hamil sebesar 37,9\% patuh pada kelompok kasus dan $56,1 \%$ pada kelompok control.

Berdasarkan hasil penelitian, uji chi square untuk mengetahui hubungan antara umur dengan kejadian BBLR, paritas dengan kejadian BBLR, jenis pekerjaan dengan kejadian BBLR dan pendapatan dengan kejadian BBLR didapatkan hasil $x^{2}$ hitung lebih kecil daripada $x^{2}$ tabel dan $p$ value lebih besar dari 0,005 menunjukkan bahwa baik umur, paritas, jenis pekerjaan, maupun pendapatan tidak berhubungan dengan kejadian BBLR.

Tabel 1.1 Analisa Bivariat Tingkat Kepatuhan Konsumsi Tablet Besi Selama Hamil dan Kejadian BBLR

\begin{tabular}{lccccc}
\hline $\begin{array}{c}\text { Kepatuhan } \\
\text { minum } \\
\text { tablet Fe }\end{array}$ & Kasus & Kontrol & Total & $\boldsymbol{x}^{\mathbf{2}}$ & $\begin{array}{c}\text { OR } \\
\mathbf{9 5 \%} \\
\mathbf{C l}\end{array}$ \\
\hline $\begin{array}{l}\text { Tidak Patuh } \\
(<90 \text { tablet })\end{array}$ & 41 & 29 & 70 & $\begin{array}{c}4,38 \\
(p=0,036)\end{array}$ & 2,09 \\
$\begin{array}{l}\text { Patuh } \\
(\geq 90 \text { tablet })\end{array}$ & 25 & 37 & 62 & & \\
\hline Total & 66 & 66 & 132 & & \\
\hline
\end{tabular}

Sumber: Data Primer 2012

Analisis hubungan antara kepatuhan mengkonsumsi tablet Fe selama hamil dengan kejadiann Bayi Berat lahir Rendah (BBLR) diperoleh hasil $x^{2}=4,38(p=0,036), O R=2,09(95 \% \mathrm{Cl}[1,044$ - 4,194]) (tabel 1.1). Hasil tersebut menunjukkan bahwa ada hubungan antara tingkat kepatuhan mengkonsumsi tablet Fe selama hamil dengan kejadian bayi berat lahir rendah (BBLR).

Hasil penelitian yang sama ditemukan oleh Falahi dkk (2011), yang menyebutkan bahwa pemberian suplementasi Fe pada wanita hamil memiliki banyak manfaat seputar pencegahan anemia defisiensi besi dengan menurunkan angka kejadian BBLR dan persalinanpremature(7). Kemudian pada hasil studi meta analisis yang dilakukan Imdad dkk (2012) menyimpulkan bahwa pemberian suplementasi $\mathrm{Fe}$ harian yang diberikan secara rutin dapat mengurangi angka kejadian BBLR sebanyak $20 \%$ dibandingkan dengan wanita hamil yang tidak mendapat suplementasi $\mathrm{Fe}(8)$.

Anemia dalam kehamilan berpengaruh buruk terhadap janin. Sekalipun tampaknya janin mampu menyerap berbagai kebutuhan dari ibunya, tetapi dengan anemia akan mengurangi kemampuan metabolisme tubuh sehingga mengganggu pertumbuhan dan perkembangan janin dalam rahim. Akibat gangguan tersebut dapat mengakibatkan persalinan prematur, bayi berat lahir rendah dan kelahiran dengan anemi(9).

Anemia pada ibu hamil salah satu penyebabnya adalah adanya proses fisiologis saat hamil, yaitu adanya penambahan volume darah ibu yang berfungsi untuk memenuhi kebutuhan sirkulasi darah ke plasenta, uterus dan payudara yang membesar dengan pembuluh yang membesar pula. 
Bertambahnya volume darah ini sayangnya tidak diikuti dengan kenaikan pembentukan sel darah merah yang memadai, sehingga konsentrasi/kadar hemoglobin ibu hamil menjadi rendah. Anemia dalam kehamilan biasanya berhubungan dengan defisiensi zat besi. Jumlah zat besi yang diabsorbsi dari makanan dan cadangan dalam tubuh biasanya tidak mencukupi kebutuhan ibu selama kehamilan sehingga penambahan asupan zat besi dapat membantu mengembalikan kadar hemoglobin(10).

\section{SIMPULAN DAN SARAN}

Ada hubungan antara tingkat kepatuhan mengkonsumsi tablet Fe selama hamil dengan kejadian bayi berat lahir rendah (BBLR), dengan risiko Ibu hamil yang tidak patuh mengkonsumsi tablet $\mathrm{Fe}$ (konsumsi kurang dari 90 tablet) adalah 2,1 kali lebih besar untuk melahirkan bayi BBLR dibanding lbu yang patuh mengkonsumsi tablet $\mathrm{Fe}$ (mengkonsumsi tablet Fe 90 tablet atau lebih).

\section{RUJUKAN}

1. Kementrian Kesehatan RI, 2010, Rencana Strategis Kementrian Kesehatan RI 2010 - 2014, Kementrian Kesehatan RI 2010, Jakarta.

2. Muslihatun, Wafi N, 2010, Asuhan Neonatus Bayi dan Balita, Fitramaya, Yogyakarta.

3. Badan Penelitian dan Pengembangan Kesehatan Kementrian Kesehatan RI, 2010, Laporan Riset
Kesehatan Dasar, Kementrian Kesehatan RI 2010, Jakarta.

4. Sulin, Djusar, 2008, "Perubahan Anatomi dan Fisiologi pada Perempuan Hamil", dalam Abdul Bari Saifuddin (Eds): IImu Kebidanan Sarwono Prawirohardjo, Edisi Keempat, pp 174-87, YBPSP, Jakarta.

5. Dinas Kesehatan Provinsi DIY, 2010, Profil Kesehatan Provinsi DIY 2010. Dinkes DIY, Yogyakarta.

6. Dep Kes RI, 2003, Program Penanggulagan Anemi Gizi pada Wanita Usia Subur (WUS). Direktorat Bina Gizi Masyarakat, Jakarta.

7. Falahi, dkk, 2011, "Impact of Prophylactic Iron Supplementation in Healthy Pregnant Women On Maternal Iron Status and Birth Outcome" dalam Food and Nutrition Bulletin The United Nation University; vol 32, pp. 213-7.

8. Imdad, A, dan Bhutta ZA, 2012, "Routine Iron/ Folate Supplementation During Pregnancy: Effect on Maternal Anemia and Birth Outcomes" dalam Paediatric And Perinatal Epidemiology; vol 26 Suppl 1, pp. 168-77.

9. Manuaba, Ida Bagus Gde, 2010, Ilmu Kebidanan, Penyakit Kandungan, dan KB untuk Pendidikan Bidan, Penerbit Buku Kedokteran, Jakarta.

10. Sulin, Djusar, 2008, "Perubahan Anatomi dan Fisiologi pada Perempuan Hamil", dalam Abdul Bari Saifuddin (Eds): IlmuKebidanan Sarwono Prawirohardjo, Edisi Keempat, pp 174-87, YBPSP, Jakarta 